\title{
Article \\ Enhancement of Strength and Resistance to Sulfate Attack in Bio-Coating Material through Negative Pressure Method for Bacteria Immobilization
}

\author{
Keun-Hyeok Yang $^{1}\left(\mathbb{D}\right.$, Seung-Jun Kwon ${ }^{2}(\mathbb{D})$ and Hyun-Sub Yoon ${ }^{1, *(\mathbb{D})}$ \\ 1 Department of Architectural Engineering, Kyonggi University, Suwon 16227, Korea; yangkh@kgu.ac.kr \\ 2 Department of Civil and Environmental Engineering, Hannam University, Daejeon 34430, Korea; \\ jjuni98@hannam.ac.kr \\ * Correspondence: lonsohs@naver.com
}

\section{check for} updates

Citation: Yang, K.-H.; Kwon, S.-J.; Yoon, H.-S. Enhancement of Strength and Resistance to Sulfate Attack in Bio-Coating Material through Negative Pressure Method for Bacteria Immobilization. Appl. Sci. 2021, 11, 9113. https://doi.org/ 10.3390/app11199113

Academic Editors: Dario De Domenico, Yeonho Park and Young-Hoon Kim

Received: 24 August 2021

Accepted: 28 September 2021

Published: 30 September 2021

Publisher's Note: MDPI stays neutral with regard to jurisdictional claims in published maps and institutional affiliations.

Copyright: (c) 2021 by the authors. Licensee MDPI, Basel, Switzerland. This article is an open access article distributed under the terms and conditions of the Creative Commons Attribution (CC BY) license (https:/ / creativecommons.org/licenses/by/ $4.0 /)$.

\begin{abstract}
In recent years, many studies have been performed on the crack repairing technique in concrete or the protection of the concrete surface against sulfate ions. Bacterial immobilization and survival rate are the dominant influencing factors for the repair of concrete. In this study, a negative pressure method (NPM) was developed to forcibly remove air in the porous materials of concrete, which was applied for surface repair through bio-coating using Rhodobacter capsualtus. For normal repair-repair using the conventional simple soaking method (SSM) and repair through NPMvarious evaluations of the concrete strength and durability were performed. Since a reinforced concrete (RC) structure for the application of these repair methods is a sewer pipe exposed to sulfate ingress, variations in concrete mass and strength were analyzed by the accelerated sulfate resistance test. The diffusion coefficient of the sulfate ion in the repair materials and the bacterial count after the accelerating test were also measured. In order to investigate the changes in the properties of the concrete hydrates, surface analyses with SEM, XRD, and TGA were carried out on the concrete under the repair layer after the tests. In all the experimental results, the bacterial immobilization rate was evaluated, and the high immobilization rate indicates the excellent shielding of sulfate ions as well as improves the survival rate of bacteria. This not only improves the service life of the coating repair but also extends the service life of the structure itself. As a result of analyzing the composition of concrete protected by different types of repair, the results most similar to the general concrete composition without sulfate attack were obtained in the case of applying NPM, which shows the least damage from sulfate attack.
\end{abstract}

Keywords: sulfate attack; bacteria; immobilization; negative pressure method; coating material

\section{Introduction}

Concrete structures have the advantages of cost effectiveness and durability; however, calcium hydroxide inside cement may form ettringite or calcium carbonate, or may even be dissolved in the outer surface, as in the case of leaching, depending on the external environment [1,2]. Deterioration factors such as chloride attack and carbonation do not have a significant effect on hardened concrete, but bring forward the corrosion initiation time of the internal reinforcement and accelerate corrosion, which may lead to critical problems in terms of structural safety. Active studies have been underway on the ion transport and reaction of deterioration factors, and in all countries, a durability design is performed before the construction of concrete structures-referred to as specifications or structural codes [3-5]. In the case of chloride attack, a number of studies have been performed considering the dissociation of chloride ions and phase equilibrium, as well as the penetration and diffusion mechanism of chloride ions [6-8]. These studies have been further extended to corrosion modeling with the consideration of the hydration degree and oxygen penetration. Some studies have developed coupled analysis modeling, which 
also considers the reduction in the structural load-carrying capacity under continuous deterioration actions [8-10]. In the case of carbonation, thermodynamic coupled analysis models have been developed, taking into account the diffusion of carbon dioxide and reactions with the hydration products inside and carbon dioxide $[8,11,12]$. The progress of the service life modeling of the sulfate attack was relatively slow because the formation of ettringite from the reaction between calcium hydroxide and sulfate ions expands the concrete volume, making quantitative modeling with a simple diffusion analysis difficult. In addition, another reason for the difficulty of a performing quantitative analysis in this context is that concrete is always exposed to the ground, and other types of deterioration factors—such as freezing and thawing - also occur in addition to sulfate attack [13,14].

In recent years, with the increase in the construction of sewer pipes and underground structures, durability design against sulfate attack has emerged as an important issue $[15,16]$. For the analysis of sulfate ingress, previous studies have mainly employed methods such as the evaluation of the deterioration depth, considering the sulfate ion diffusion coefficient and the cement components [14,17], evaluation of the rate of strength reduction through an accelerated sulfate ion resistance test [13,18], or diffusion analysis considering the multiple deteriorated layers $[19,20]$. Furthermore, underground structures are always exposed to ground water and are difficult to maintain, so repair techniques that are resistant to bio-chemical deterioration are required. For a long time, organic material-epoxy and inorganic material-cement mortar have conventionally been used for repairing materials, and recently, polymer-cement materials have been widely adopted for enhancing adhesion and decreasing the curing period [21,22]. Using inorganic coating is currently very effective and has a good cost-benefit ratio in the short term, however, many problems have been reported due to the peeling-off and delamination of the coating layer due to its different dimensional integrity, which cannot guarantee a long service life after repair. Polymer-cement-based material has engineering advantages such as high resistance to chloride ingress and adhesive strength; however, it has a relatively high repair price and several defects have been reported in instances of low-quality material and construction skills [23]. The previously mentioned techniques are usually utilized for resisting chloride ingress and carbonation progress since the main deterioration mechanism is not bio-chemical penetration but diffusion and permeation. The sewage structure is a representative one which is directly deteriorated by bio-chemical attack; however, very limited studies have been carried out for durability design against bio-chemical action such as sulfate ingress.

Meanwhile, concrete repair techniques using bacteria are drawing attention due to the various deteriorating agents causing bio-chemical erosion. The technique with bacteria is also known to improve water permeability, chloride penetration resistance, and the sulfate resistance of concrete through healing cracks or blocking the pores caused by calcium carbonate and slime formed by bacterial growth $[19,24,25]$. However, studies applying bacteria to concrete have mainly focused on simply covering over cracks with calcium carbonate generated by consuming carbon dioxide and calcium hydroxide [24-27]. In most studies, positive outcomes such as improving the density of the microstructure, increasing strength, and reducing the absorption rate of cement-hardened bodies by calcium carbonate formed by bacteria have been confirmed. [28,29]. In addition, many researchers use a method of directly injecting bacteria when blending or immersing a concrete sample in a culture during the curing process for the immobilization of the bacteria. Ramachandrans et al. [30] pointed out that bacteria with optimal growth efficiency in neutral environments may hinder continuous growth and proliferation when introduced into strong alkaline concrete environments. Another study [31] pointed out that even a sufficient supply of moisture and nutrients, as well as sufficient room for the growth of pores will result in internal moisture and decreased voids due to the continuous hydration and drying of the concrete. In other words, the study of improving the immobilization rate is very important since the growth rate of bacteria present in concrete or repair layers is crucial for continuous crack recovery and mitigating degradation in the concrete's performance. 
In this study, a negative pressure method (NPM) was proposed to enhance the bacteria immobilization, and the strength characteristics of the coating materials and hydration products with bacteria were analyzed in comparison with the results from the conventional repairing method. In addition, for evaluating the resistance to sulfate ingress, the strength and mass change characteristics of the repaired concrete after being submerged in sulfuric acid were analyzed, and the sulfate ion diffusion coefficient was evaluated. The result of the analysis showed that the proposed technique not only improved the mechanical properties but also the durability characteristics compared to the conventional bacterial immobilization technique.

\section{Damage in Sewage Concrete Structure Due to Bio-Chemical Deteriorations}

The causes of the deterioration of a sewage concrete structure include physical erosion, such as erosion from the flow of water, however, chemical erosion is the main cause of the actual deterioration of sewage structures. The effects of various deteriorating agents interplay and in combination produce a strong deterioration mechanism; however, the bio-chemical deterioration induced by bacteria inhabiting sewage or municipal wastewater needs to be considered with priority for structure maintenance. In structures such as those of sewage systems, the corrosion of concrete is initiated by the bio-chemical activities of aerobic or anaerobic bacteria through the organic pollutants contained in streams and soil. In previous studies, the corrosion of the concrete surface and decomposition of internal hydration products were identified through the sulfate ion reducing bacteria, Thiobacillus thiooxidans [32,33]. The bio-chemical deterioration of concrete has been reported to being with the reduction of sulfate ions into hydrogen sulfide gas by bacteria utilizing sulfide, which involves complex biological and chemical reactions. The bio-chemical deterioration is known to consist of three stages [33], as shown in Figure 1.

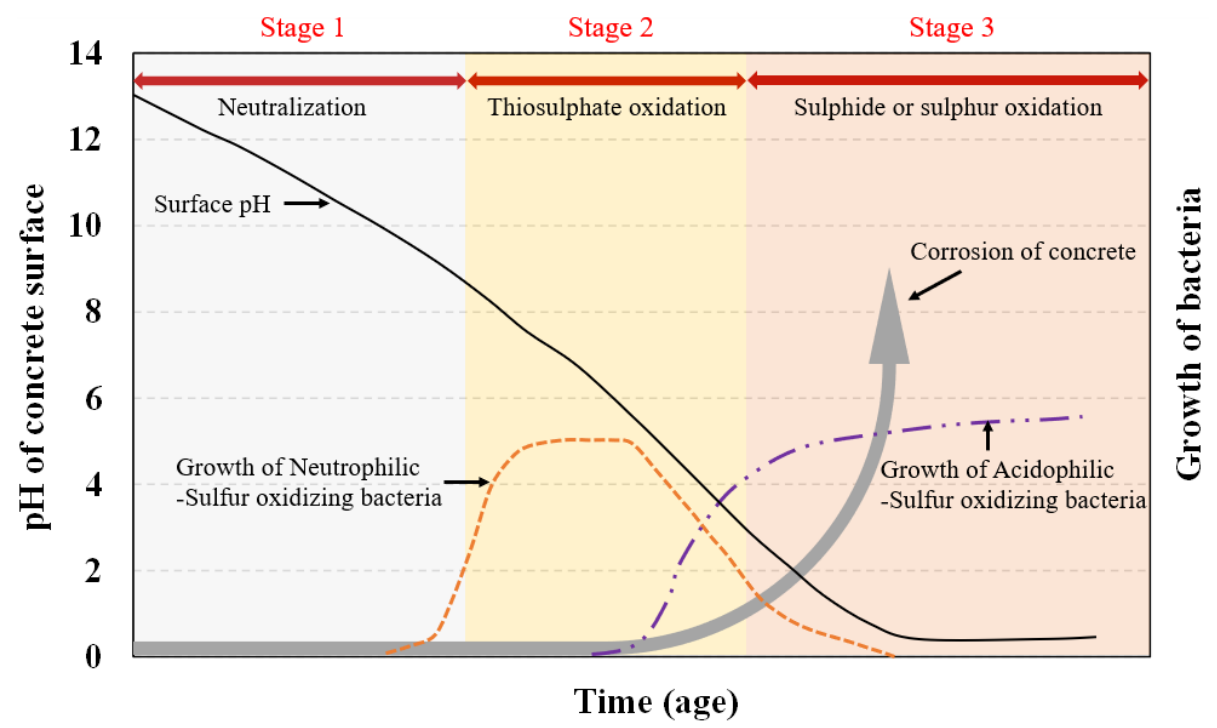

Figure 1. Stages of bio-chemical corrosion in a sewage environment.

The first stage starts with the growth of sulfate-reducing bacteria in an anaerobic sewage environment and the consequent generation of hydrogen sulfide gas. The municipal wastewater flowing into the sewer pipe is deposited in the lower part of the pipe in the form of sludge [34]. Anaerobic bacteria inhabiting this deposition layer reduce sulfate ions $\left(\mathrm{SO}_{4}{ }^{2-}\right)$ to hydrogen sulfide $\left(\mathrm{H}_{2} \mathrm{~S}\right)$ in the process of decomposing and consuming the organic matter required by nutrients during bacterial growth, which generates a large amount of hydrogen sulfide gas [35]. In the process, instead of oxygen $\left(\mathrm{O}_{2}\right)$, oxygen bound to sulfide $(S)$ is utilized for the purpose of protein synthesis and energy acquisition necessary for the growth of anaerobic bacteria, inducing anaerobic respiration (oxygen-free respiration) in which organic matter is oxidized. In this process, thiosulfate ions $\left(\mathrm{S}_{2} \mathrm{O}_{3}{ }^{2-}\right)$ 
and tetra-thionite ions $\left(\mathrm{S}_{4} \mathrm{O}_{6}{ }^{2-}\right)$ are generated as shown in Equation (1), and a hydrogen ion $(\mathrm{H}+)$ generated during the decomposition of organic matter present in the sewage deposits is bound to $\mathrm{S}^{2-}$, which is generated during the decomposition of $\mathrm{SO}_{4}{ }^{2-}$ to produce $\mathrm{H}_{2} \mathrm{~S}$. Figure 2 shows the process of hydrogen sulfide $\left(\mathrm{H}_{2} \mathrm{~S}\right)$ generation through anaerobic respiration [36,37]:

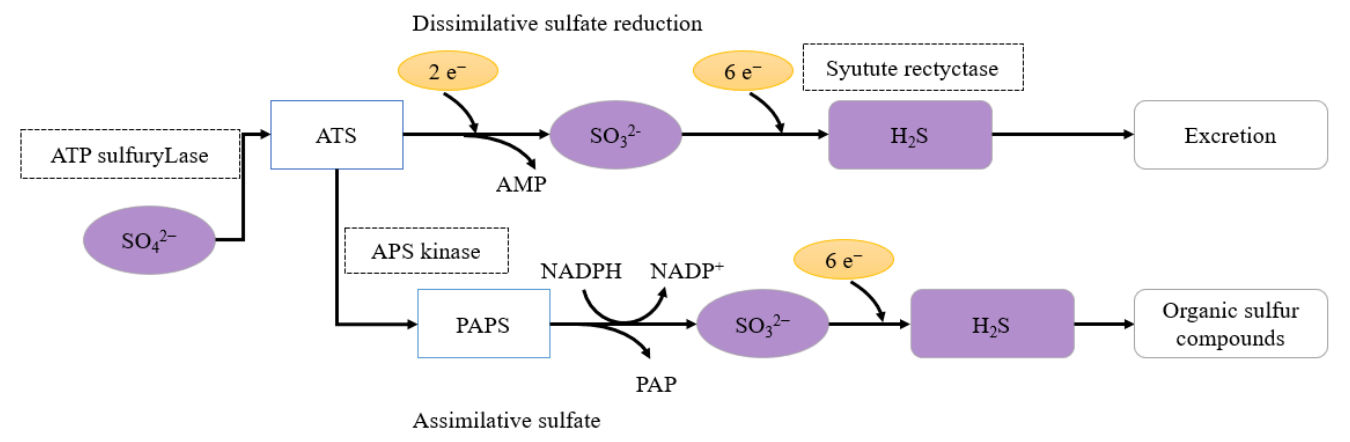

Figure 2. Metabolic reaction process of sulfate-reducing bacteria.

$$
\begin{aligned}
& \mathrm{SO}_{4}{ }^{2-}+\mathrm{ATP} \rightarrow \text { adenosylphosphate }- \text { sulfate }(\mathrm{APS}) \rightarrow \mathrm{SO}_{3}{ }^{2-}(+\mathrm{AMP}) \\
& \mathrm{S}_{3} \mathrm{O}_{6}{ }^{2-} \rightarrow \mathrm{S}_{2} \mathrm{O}_{3}{ }^{2-}\left(+\mathrm{SO}_{3}{ }^{2-}\right)
\end{aligned}
$$

The $\mathrm{pH}$ of the internal pore solution in concrete is maintained between approximately 12 and 13 due to the effect of calcium hydroxide $\left[\mathrm{Ca}(\mathrm{OH})_{2}\right]$ and calcium silicate hydrate $(\mathrm{C}-\mathrm{S}-\mathrm{H})$, which are initial cement hydrates. However, the $\mathrm{pH}$ of concrete is reduced to below 10 or lower due to the effect of acidic ions $\left(\mathrm{H}_{2} \mathrm{~S}, \mathrm{~S}_{2} \mathrm{O}_{3}{ }^{2-}, \mathrm{S}_{4} \mathrm{O}_{6}{ }^{2-}\right)$ generated by sulfate ion-reducing bacteria and carbonation [38,39]. In addition, lowering the $\mathrm{pH}$ of concrete structures induces the proliferation of sulfur oxidizing bacteria having optimal growth efficiency in a neutral environment ( $\mathrm{pH} 9$ or lower).

The second stage of bio-chemical deterioration starts from the lowered $\mathrm{pH}$ of the sewage concrete, as described above, and in this stage, the deterioration level gradually increases due to the proliferation of the colony of sulfur-oxidizing bacteria growing on the concrete surface exposed to sulfate ions. Initially, due to the growth of neutro-philic sulfur-oxidizing bacteria, which can grow in a neutral $\mathrm{pH}$ environment, polythionic acid, a sulfur-based chemical substance, is generated, and thus the $\mathrm{pH}$ of the concrete surface is further lowered [21]. During the process of reducing sulfate ions, $\mathrm{S}_{2} \mathrm{O}_{3}{ }^{2-}$ and sulfide (S) are generated as intermediates, acting as an energy source for sulfur-oxidizing bacteria [40]. The third stage of the bio-chemical deterioration of concrete by acidophilic sulfur oxidizing bacteria is the formation of sulfuric acid through the supply of oxygen and water. Sulfuroxidizing bacteria generate sulfuric acid in the process of acquiring energy for proliferation and growth, and the generated sulfuric acid causes circulating deterioration through a chemical reaction with cement hydrates on the surface of the sewer pipe in contact with the microbial colony.

Through the above stages, when the concrete surface is exposed to a sulfate-dominant environment, sulfuric acid reacts with cement hydrates to produce dihydrate gypsum $\left(\mathrm{CaSO}_{4} \cdot 2 \mathrm{H}_{2} \mathrm{O}\right)$ and anhydrous gypsum $\left(\mathrm{CaSO}_{4}\right)$, as shown in Equations (2) and (3) [34]. Dihydrate gypsum is a water-soluble material, and as it easily dissolves inside the cement matrix, the structure becomes porous, accelerating the degradation of concrete. In addition, as shown in Equation (4), anhydrous gypsum reacts with aluminate $\left(\mathrm{C}_{3} \mathrm{~A}, 3 \mathrm{CaO} \cdot \mathrm{Al}_{2} \mathrm{O}_{3}\right)$ in cement to form ettringite $\left(3 \mathrm{CaO} \cdot \mathrm{Al}_{2} \mathrm{O}_{3} \cdot 3 \mathrm{CaSO}_{4} \cdot 32 \mathrm{H}_{2} \mathrm{O}\right)$, leading to volume expansion and threatening dimensional stability, and thus resulting in cracks [41]. Indeed, these cracks accelerate the intrusion of external deteriorating agents and have a critical effect on the corrosion of internal reinforcing bars [42]:

$$
\mathrm{Ca}(\mathrm{OH})_{2}+\mathrm{H}_{2} \mathrm{SO}_{4} \rightarrow \mathrm{CaSO}_{4} \cdot 2 \mathrm{H}_{2} \mathrm{O}
$$




$$
\begin{gathered}
\mathrm{CaO} \cdot \mathrm{SiO}_{2} \cdot 2 \mathrm{H}_{2} \mathrm{O}+\mathrm{H}_{2} \mathrm{SO}_{4} \rightarrow \mathrm{CaSO}_{4}+\mathrm{Si}(\mathrm{OH})_{4}+\mathrm{H}_{2} \mathrm{O} \\
3 \mathrm{CaO} \cdot \mathrm{Al}_{2} \mathrm{O}_{3}+3\left(\mathrm{CaSO}_{4} \cdot 2 \mathrm{H}_{2} \mathrm{O}\right)+26 \mathrm{H}_{2} \mathrm{O} \rightarrow 3 \mathrm{CaO} \cdot \mathrm{Al}_{2} \mathrm{O}_{3} \cdot 3 \mathrm{CaSO}_{4} \cdot 32 \mathrm{H}_{2} \mathrm{O}
\end{gathered}
$$

\section{Test Plan for Enhanced Immobilization of Bacteria through NPM}

\subsection{Development of Negative Pressure Process}

The cement matrix has a strong alkaline component, so that securing sufficient moisture and organic nutrients becomes difficult to ensure bacteria survival. The bacterial immobilization method refers to a method of securing living pores that bacteria need for continuous growth and proliferation. The negative pressure method creates a negative pressure environment of 10-20 torr by injecting bacteria culture media in which immobilization material is immersed in a sealed container, thus forcibly releasing and thereby removing the internal air. This way, negative pressure is generated by forcibly discharging the air in the pores inside the immobilization material, and the bacterial cells and culture media are rapidly transported to the pores and immobilization is completed. In Figure 3, the process and mechanism of the negative pressure method are illustrated with the related photos.

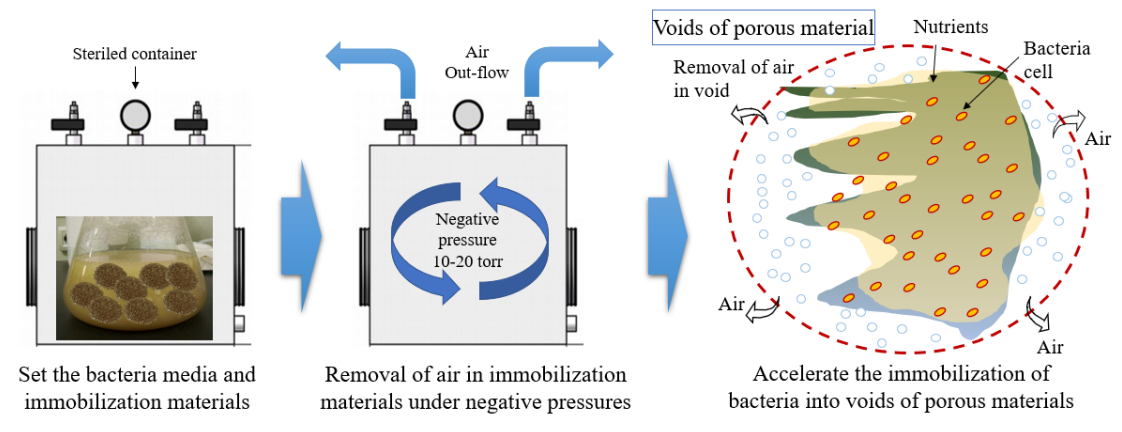

(a)

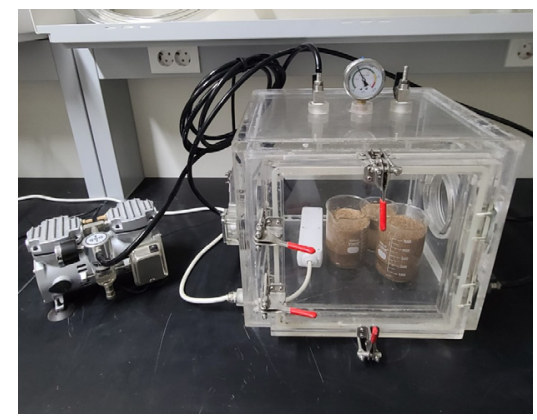

(b)

Figure 3. Negative pressure technique with the bacteria immobilization mechanism: (a) schematic diagram of the negative pressure device for improved bacteria immobilization; (b) photos for the negative pressure device.

\subsection{Test Program Outline for Engineering Property Evaluation}

\subsubsection{Used Bacteria and Cementitious Materials}

Various tests were performed by comparing the results from the negative pressure method with the conventional method for bacteria mixing. Referring to the previous studies [20,43], the mix proportion of the repair material and the used bacteria were selected. The growth of bacteria and the strength of repairs mixed with bacteria were evaluated. Evaluations of the sulfate resistance and the properties of hydrates in concrete were also performed considering the conditions of repair coating. In addition, a natural cell test was performed for the measurement of the diffusion coefficient, which is an important parameter for the quantification of sulfate ingress. Table 1 outlines the properties of ordinary Portland cement (OPC), ground granulated blast furnace slag (GGBFS), and the fly ash (FA) used as binders for the mixing of repairs. Table 2 lists the mix proportions of repairs with bacteria (bio-coating materials). The bacteria used in this study are Rhodobacter 
capsulatus, which forms slimes (glycocalyx) on the outer concrete surface in a harsh external environment. The slimes that these bacteria form while inhabiting the concrete surface immobilize sulfate ions and inhibit the growth of sulfate-reducing bacteria, thus also inhibiting the generation of hydrogen sulfide gas and sulfate that cause the chemical deterioration of concrete. As referred to in the previous study [24], culture media were prepared, and the bacteria were cultured at a concentration of $10^{9}$ cells $/ \mathrm{mL}$ for 10 days for the test. The repair mix was divided in the case of adding expanded vermiculite with immobilized bacteria cultured at a concentration of $10^{9}$ cells $/ \mathrm{mL}$ and the case without adding the expanded vermiculite. Expanded vermiculite is a porous material to provide living pores of bacteria, with a pore diameter of $0.25-0.36 \mathrm{~mm}$ and a density of $0.25 \mathrm{~g} / \mathrm{cm}^{3}$.

Table 1. Properties of cementitious materials for coating materials.

\begin{tabular}{|c|c|c|c|c|c|c|c|c|c|c|c|c|}
\hline \multirow[b]{2}{*}{ Materials } & \multicolumn{2}{|c|}{ Physical Properties } & \multicolumn{10}{|c|}{ Chemical Composition (wt.\%) } \\
\hline & $\begin{array}{l}\text { Density } \\
\left(\mathrm{g} / \mathrm{cm}^{3}\right)\end{array}$ & $\begin{array}{l}\text { Fineness } \\
\left(\mathrm{cm}^{2} / \mathrm{g}\right)\end{array}$ & $\mathrm{SiO}_{2}$ & $\mathrm{Al}_{2} \mathrm{O}_{3}$ & $\mathrm{Fe}_{2} \mathrm{O}_{3}$ & $\mathrm{CaO}$ & $\mathrm{MgO}$ & $\mathrm{SO}_{3}$ & $\mathrm{TiO}_{2}$ & $\mathrm{Na}_{2} \mathrm{O}$ & $\mathrm{K}_{2} \mathrm{O}$ & LOI \\
\hline $\mathrm{OPC}$ & 3.15 & 3260 & 21.7 & 5.3 & 3.1 & 62.4 & 1.6 & 1.7 & - & - & - & 0.8 \\
\hline GGBFS & 2.94 & 4355 & 33.5 & 15.2 & 0.5 & 45.6 & 2.6 & 2.5 & 0.9 & 0.2 & 0.4 & 0.7 \\
\hline FA & 2.23 & 3720 & 53.3 & 27.9 & 7.8 & 6.8 & 1.1 & 0.8 & - & 0.6 & 0.8 & 0.9 \\
\hline
\end{tabular}

Table 2. Mix proportions of bio-coating materials' immobilization conditions.

\begin{tabular}{|c|c|c|c|c|c|c|c|c|}
\hline \multirow{2}{*}{ Specimens } & \multirow{2}{*}{ W/B } & \multirow{2}{*}{ S/B } & \multicolumn{3}{|c|}{$\begin{array}{c}\text { Binder Composition } \\
\text { (wt.\%) }\end{array}$} & \multirow{2}{*}{$\begin{array}{l}\text { Bacteria } \\
\text { Strain }\end{array}$} & \multirow{2}{*}{$\begin{array}{c}\text { Type of } \\
\text { Immobilization } \\
\text { Method }\end{array}$} & \multirow{2}{*}{$\begin{array}{c}\text { Replacement Ratio of } \\
\text { Bacteria Carrier by the } \\
\text { Volumetric Fraction of } \\
\text { Sand }\end{array}$} \\
\hline & & & OPC & FA & GGBFS & & & \\
\hline Normal repair & \multirow{3}{*}{0.35} & \multirow{3}{*}{2} & \multirow{3}{*}{35} & \multirow{3}{*}{20} & \multirow{3}{*}{45} & - & - & - \\
\hline $\begin{array}{l}\text { Bio-simply } \\
\text { soaking }\end{array}$ & & & & & & \multirow{2}{*}{$\begin{array}{l}\text { Rhodobacter } \\
\text { capsulatus }\end{array}$} & Simply soaking & 35 \\
\hline $\begin{array}{l}\text { Bio-negative } \\
\text { pressure }\end{array}$ & & & & & & & $\begin{array}{l}\text { Negative } \\
\text { pressure }\end{array}$ & 35 \\
\hline
\end{tabular}

\subsubsection{Bacteria Activity and Growth}

The count of immobilized bacteria on the porous material and the sustained growth of bacteria in the hardened repair materials were evaluated using the bacterial count of re-cultured bacteria isolated from the porous material and the repair material. One gram of crushed samples from the porous material after the immobilization and the repair material were added to $50 \mathrm{~mL}$ of inorganic medium and bacteria desorption was performed for $3 \mathrm{~h}$ in a shaking incubator at $30^{\circ} \mathrm{C}$. Then, the desorbed bacteria culture medium was diluted at a dilution factor of $10^{-6}$, and $100 \mathrm{mg}$ of the diluted sample was inoculated to agar medium, prepared as shown in Table 3, before being cultured for 3 days. The average bacterial count was derived by counting the bacterial colonies formed on the cultured agar medium. 
Table 3. Medium composition for culturing Rhodobacter capsulatus.

\begin{tabular}{cc}
\hline Nutrients & Quantity \\
\hline Yeast extract & $1.0 \mathrm{~g} / \mathrm{L}$ \\
\hline Disodium succinate hexahydrate & $1.0 \mathrm{~g} / \mathrm{L}$ \\
\hline Absolute ethanol & $1 \mathrm{~mL} / \mathrm{L}$ \\
\hline $\mathrm{KH}_{2} \mathrm{PO}_{4}$ & $0.5 \mathrm{~g} / \mathrm{L}$ \\
\hline $\mathrm{MgSO}_{4} \cdot \mathrm{H}_{2} \mathrm{O}$ & $0.4 \mathrm{~g} / \mathrm{L}$ \\
\hline $\mathrm{CaCl}_{2} \cdot \mathrm{H}_{2} \mathrm{O}$ & $0.005 \mathrm{~g} / \mathrm{L}$ \\
\hline $\mathrm{NaCl}$ & $0.4 \mathrm{~g} / \mathrm{L}$ \\
\hline Trace-element solution & $1 \mathrm{~mL} / \mathrm{L}$ \\
\hline Carbon source: malic acid & Medium wt. $\times 0.3 \%$ \\
\hline
\end{tabular}

\subsubsection{Strength and Resistance to Sulfate Attack}

The specimen used for the evaluation of the strength of the bio-coating material (repair with mixed bacteria) was prepared as described in ASTM C 39. After curing in an environment of $20{ }^{\circ} \mathrm{C}$ with R.H. of $60 \pm 5 \%$ for 3 days, the mold was removed and the specimen was further cured in an underwater environment at $20{ }^{\circ} \mathrm{C}$ for 28 days. In the case of the sulfuric acid solution immersion test, the evaluation was performed by coating the repair material on the cured concrete specimen with a diameter of $100 \mathrm{~mm}$ and a height of $200 \mathrm{~mm}$. The repair material was coated on the concrete with a thickness of $2.5 \mathrm{~mm}$ on the 28th day in consideration of the economic aspect and the efficient repair of the concrete sewage structure. Specimens coated with bio-coating material were cured underwater at $20{ }^{\circ} \mathrm{C}$ during 28 days, and immersed in $5 \%$ sulfuric acid solution as described in ASTM C 7401. Then, with increasing immersion periods (1, 7 and 28 days), the compressive strength and mass of the specimen were evaluated based on ASTM C 39 and ASTM C 642. Three samples were prepared and the averages were used for the results. The variations in compressive strength in the sulfuric acid solution were compared considering the repair conditions and duration period.

For the evaluation of the sulfate ion diffusion coefficient, a natural diffusion cell test was adopted. As described in ASTM C 1202, after a specimen was placed between two cells, the change in ion concentration was monitored as a function of time, and the result was derived as shown in Equation (5):

$$
D_{i}=\frac{V \Delta Q}{A \Delta T} \times \frac{L}{c_{1}-c_{2}}
$$

where $V$ is the volume of the diffusion cell $\left(\mathrm{m}^{3}\right) ; \Delta Q$ is the increase in sulfate ion concentration in the cell containing deionized water $\left(\mathrm{kg} / \mathrm{m}^{3}\right) ; A$ is the exposed area of the sliced specimen $\left(\mathrm{m}^{2}\right) ; \Delta T$ is the elapsed time after starting the test (s); $L$ is the thickness of the sliced specimen $(\mathrm{m}) ; c_{1}$ is the concentration of the sulfate ion solution $\left(\mathrm{kg} / \mathrm{m}^{3}\right)$; and $c_{2}$ is the average concentration of the cell containing deionized water $\left(\mathrm{kg} / \mathrm{m}^{3}\right)$.

The diffusion coefficient was evaluated by retaining the specimen for 56 days, after which the concentration became almost constant under steady condition. The volume of the cell containing the solution with sulfate ions $\left(\mathrm{SO}_{4}{ }^{2-}\right)$ and the deionized water was $0.001 \mathrm{~m}^{3}$, and the concentration of sulfate ion in the solution with sulfate ions was set to $120 \mathrm{ppm}\left(1.24 \mathrm{~mol} / \mathrm{m}^{3}\right)$. The thickness of the repair material slice was $5 \mathrm{~mm}$, and the area exposed to deionized water and the sulfate ion solution was $70 \mathrm{~mm} \times 70 \mathrm{~mm}$. In addition, the change in the sulfate ion concentration in the cell was recorded using an ion meter with which data can be checked in real time. Figure 4 shows the specimen preparation for evaluating the resistance to the sulfate ingress of bio-coating material and photos for the test. 


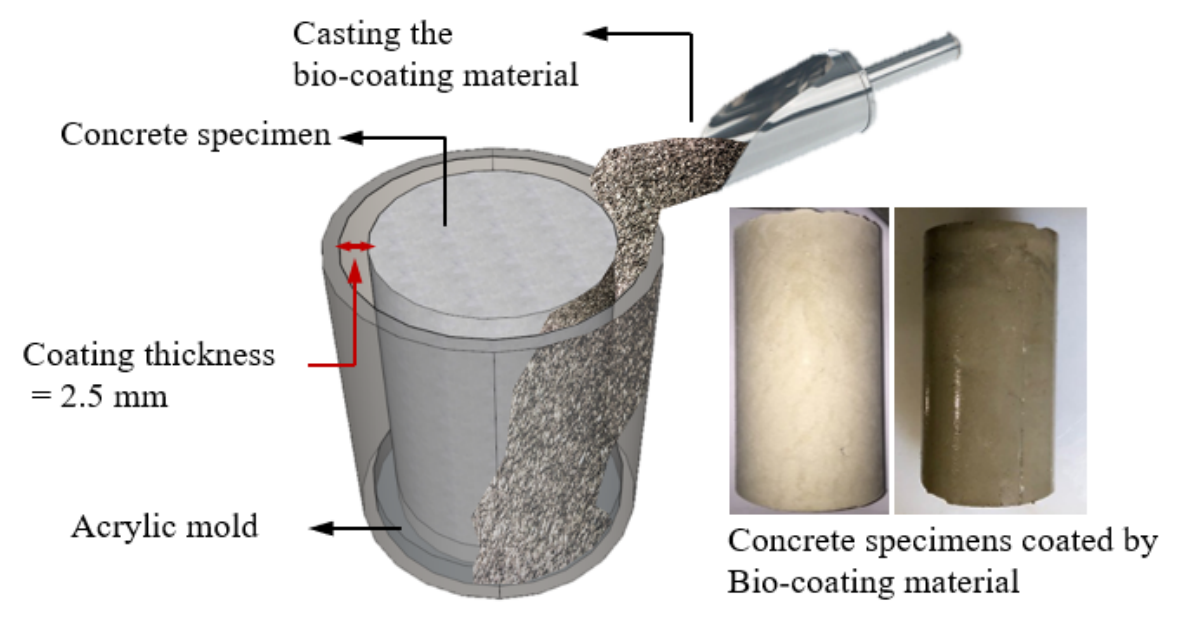

(a)
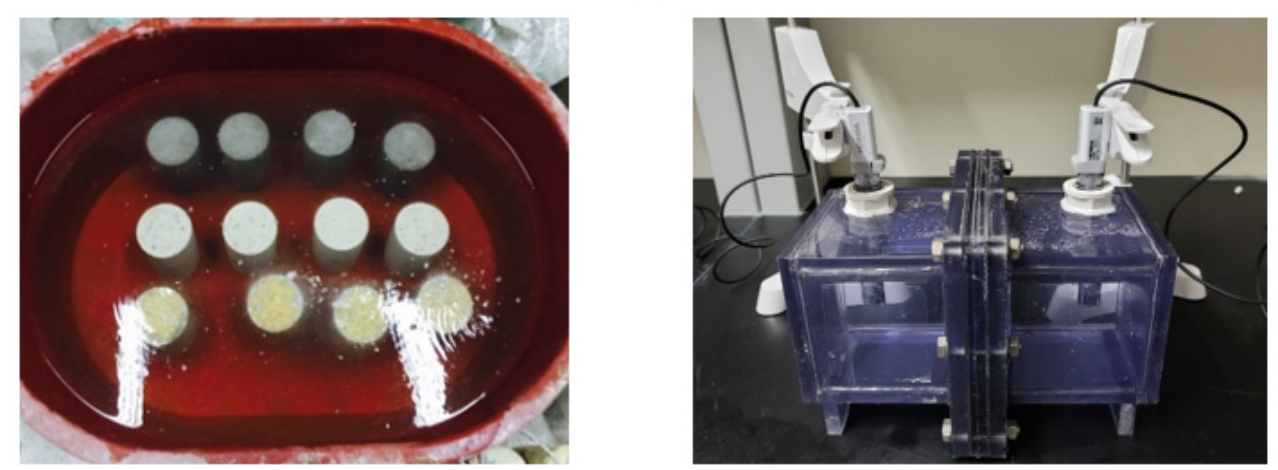

(b)

Figure 4. Photos of the resistance to sulfate ingress in bio-coating material with the negative pressure method: (a) preparation of the specimen coated with bio-coating material for the evaluation of the resistance to sulfate ingress; and (b) immersion in the sulfuric acid solution and sulfate ion diffusion coefficient.

\subsubsection{Strength and Resistance to Sulfate Attack}

Changes in the properties of the cement hydrates after immersion in the sulfuric acid solution in the concrete cylinder coated with bio-coating material were examined using X-ray diffraction (XRD) analysis and TGA-DTG analysis after 28 days of immersion. XRD patterns were measured on a Philips X'pert pro-MRD spectrometer with a scan rate of $4.2^{\circ} / \mathrm{min}$ in the measurement range between $5^{\circ}$ and $90^{\circ}$. The thermogravimetric analysis (TGA) and derivative thermogravimetric (DTG) curves for the concrete surface deterioration specimens were measured using STA 409 PC, a thermal analysis instrument. The rate of the increase in temperature for thermal analysis was set to $10^{\circ} \mathrm{C} / \mathrm{min}$, and the maximum temperature was $1000^{\circ} \mathrm{C}$. Figure 5 shows the XRD and TGA equipment used. 


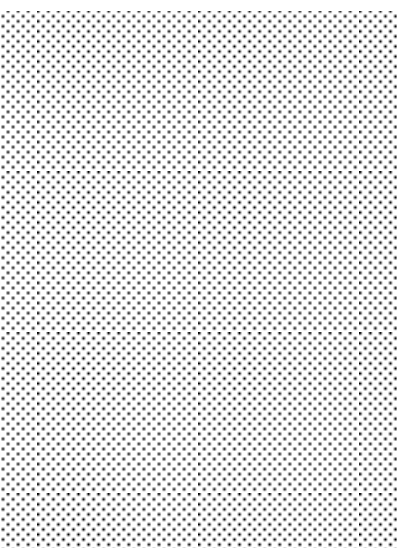

(a)

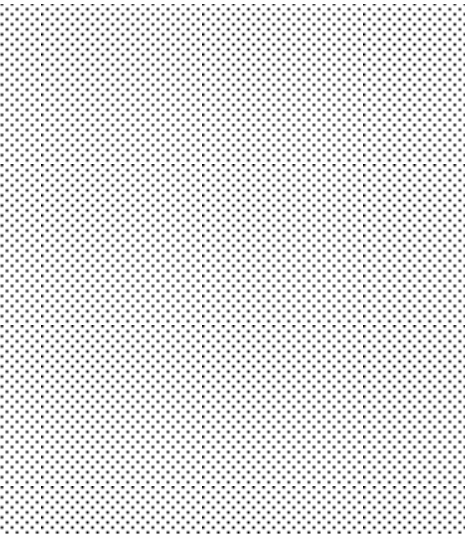

(b)

Figure 5. Photos of the chemical composition analysis equipment: (a) XRD equipment; and (b) TGA equipment.

\section{Test Results and Discussion}

\subsection{Enhanced Bacteria Activity}

The results of the evaluation of bacterial counts from the simple soaking method (SSM) and negative pressure method (NPM) are shown in Figure 6. In the expanded vermiculite in which immobilization was induced by NPM, the bacteria of $1.2 \times 10^{9}$ cells $/ \mathrm{mL}$ were immobilized within $3 \mathrm{~h}$, whereas with SSM, $3.6 \times 10^{8}$ cells $/ \mathrm{mL}$ of bacteria were immobilized for the same period. The method of creating a negative pressure condition showed 3.3 times higher immobilization efficiency than SSM, and an approximately 2.2 times higher immobilization rate after $72 \mathrm{~h}$. These results indicate that when considering the bacterial concentration $\left(10^{9}\right.$ cells $\left./ \mathrm{mL}\right)$ in utilizing slime-forming bacteria capable of protecting against sulfate deterioration in concrete, NPM can immobilize larger numbers of bacterial cells in a shorter amount of time, which yields enhanced resistance to the sulfate attack for repair materials.

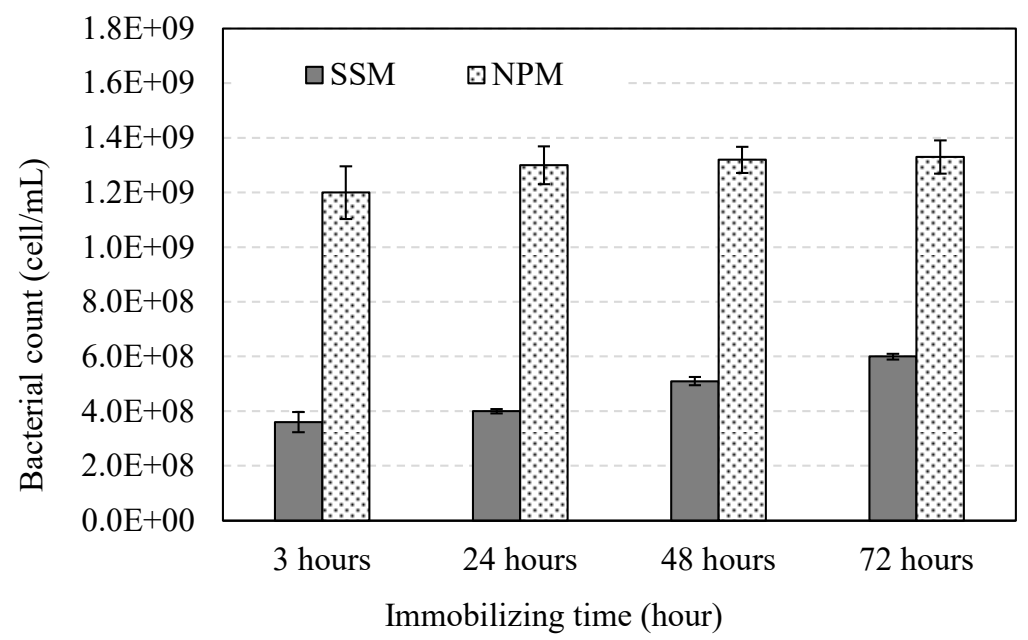

Figure 6. Effect of immobilization techniques on the population of bacteria in expanded vermiculite.

\subsection{Enhanced Resistance to Sulfate Ingress}

The result of evaluating the compressive strength of a bio-coating material with bacteria is shown in Figure 7. The compressive strength of the bio-coating material did not show a significant difference regardless of the condition and treating bacterial immobilization. The compressive strength at 7 and 28 days of normal repair without bacteria mixing was 22.1 MPa and 38.9 MPa, respectively. The compressive strength of the specimen by SSM at 28 days was $40.7 \mathrm{MPa}$, showing the highest strength. The compressive strength at 7 days 
was $22.6 \mathrm{MPa}$, indicating that the compressive strength was higher than that of normal repair without bacteria mixing at all ages. The compressive strength of the specimen by NPM was $39.8 \mathrm{MPa}$, which was slightly lower than that of the SSM specimen, however, the difference was negligible at approximately $2 \%$. The compressive strength of this specimen at 7 days of age was $21.4 \mathrm{MPa}$, which is similar to that of the SSM specimen.

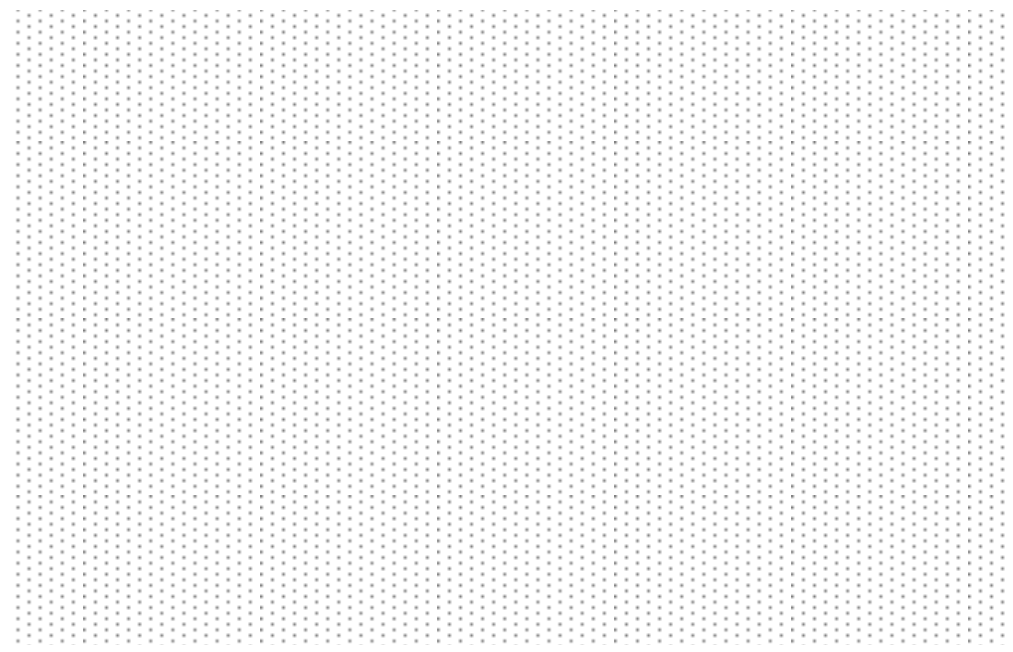

Figure 7. Compressive strength development of bio-coating materials.

Figure 8 shows the changes in the compressive strength of the same specimens by days after immersion in the $5 \%$ sulfuric acid solution. The compressive strength of the cylindrical concrete without the bio-coating material before being immersed in sulfuric acid solution was $35 \mathrm{MPa}$. The compressive strength measurements of the sulfuric acid solution immersion showed that the results of all specimens showed a continuously decreasing trend after sulfuric acid solution immersion due to chemical erosion. The decreasing rate of compressive strength showed the largest change in the case of normal repair without bacteria, from $9 \%$ at 7 days to $14 \%$ at 28 days. The rate of the decrease in the specimen using repairs with Rhodobacter capsualtus by SSM was $8 \%$ at 28 days of sulfuric acid solution immersion. The rate of the decrease in the concrete specimen with the bacteria immobilized by NPM was $1 \%$ at 7 days and $5 \%$ at 28 days of sulfuric acid solution immersion, indicating the smallest decrease in strength by sulfate deterioration among all the specimens. This indicates that the performance of the repair treated with NPM was maintained for a long time under the sulfate ingress condition, demonstrating the effectiveness of the NPM.

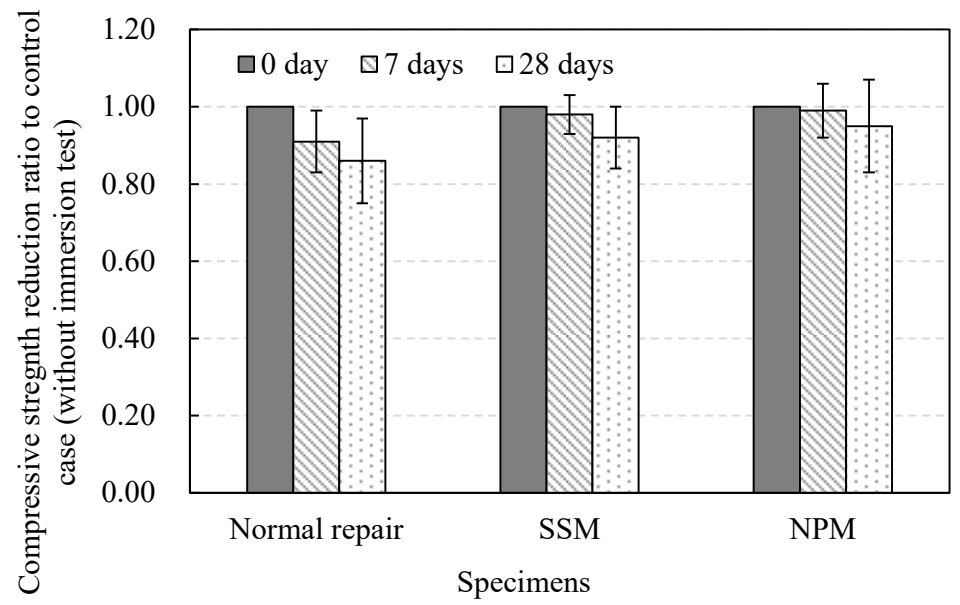

Figure 8. Compressive strength variation of the coated concretes immersed in $5 \%$ sulfuric acid solution. 
The mass variation in the concrete coated with bio-coating material after immersion in sulfuric acid solution also showed a similar tendency to the variation in compressive strength, as shown in Figure 9. The decrease in the mass of the concrete after 28 days of immersion was the highest at $7 \%$ in the concrete coated with the normal repair. The decrease in the mass of the SSM specimen and the NPM specimen after 28 days of immersion was $5 \%$ and $2 \%$, respectively, showing that the repair layer prepared by creating a negative pressure environment to serve as an effective protection material against sulfate ingress.

The volume expansion due to ettringite and gypsum-which are hydrates of deterioration formed through the reaction of cement hydrates such as $\mathrm{Ca}(\mathrm{OH})_{2}$ and CSH gel with sulfuric acid $\left(\mathrm{H}_{2} \mathrm{SO}_{4}\right)$ - causes the cement matrix to crack as well as a decrease in the compressive strength of the concrete $[13,17]$. The decrease in the compressive strength and mass of the concrete exposed to sulfuric acid can be significantly improved by applying repairs with slime coating with bacteria. This is because, as shown in Figure 10, the reaction between the cement hydrates and $\mathrm{H}_{2} \mathrm{SO}_{4}$ was inhibited due to the block effect of the deterioration factors of bacterial slime formed on the surface of the repairs $[19,20]$.

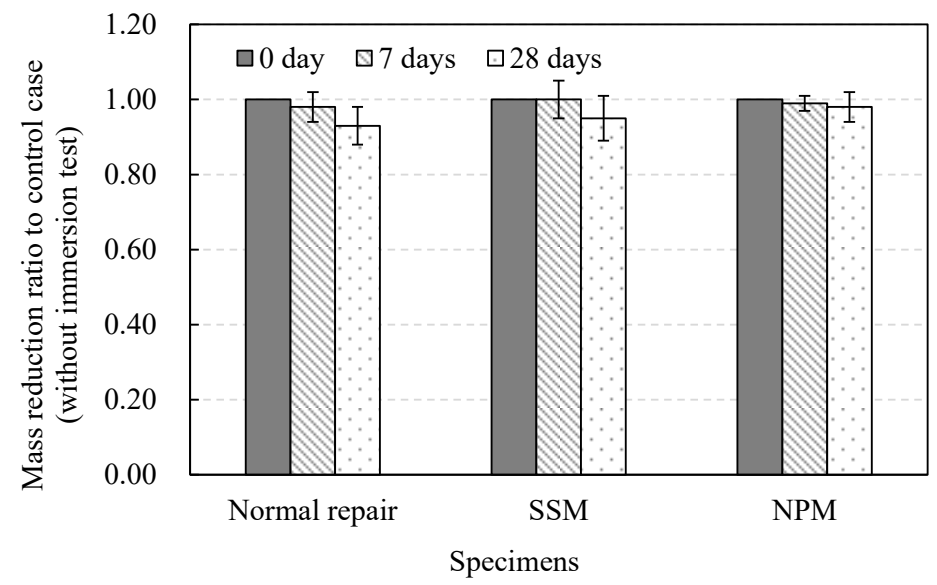

Figure 9. Mass variation of the coated concretes immersed in 5\% sulfuric acid solution.

The bacterial count may be another index for the quantification of the soundness of a repair material so that it was evaluated after 28 days of immersion in the $5 \%$ sulfuric acid solution. The specimen with NPM had a concentration of Rhodobacter capsulatus at $6.7 \times 10^{6}$ cells $/ \mathrm{mL}$. On the other hand, that with SSM was $2.1 \times 10^{6}$ cell $/ \mathrm{mL}$, indicating that the immobilization rate of NPM specimen was more than 3.0 times higher. The same tendency was repeated for the results of strength reduction and mass loss. Figure 10 shows the bio-slime layer at $90 \mu \mathrm{m}$ thickness identified through SEM analysis, and Figure 11 shows the difference in the growth of bacteria according to the culturing method and the change in the concentration of bacteria under the sulfate resistance test condition.

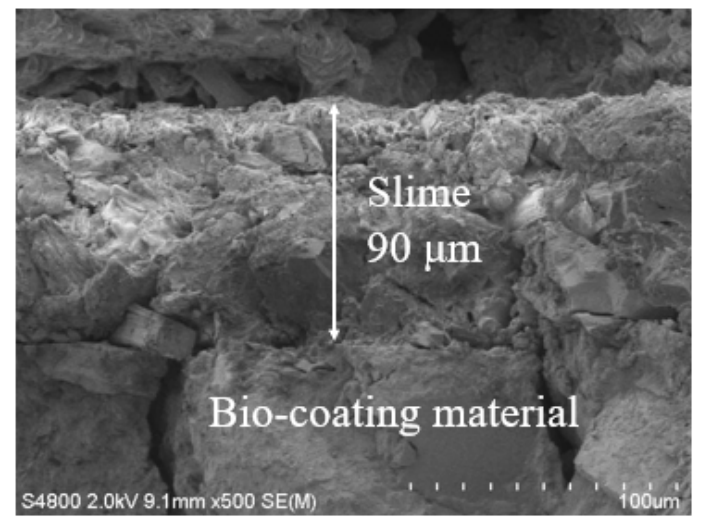

Figure 10. Typical SEM image of slime formed on the surface of bio-coating material (NPM). 
For the sulfate ion diffusion coefficient of the bio-coating material, the average value of three specimens was used, and the results are shown in Figure 12. The sulfate ion diffusion coefficient measured by diffusion cell test showed the highest value of $2.09 \times 10^{-12} \mathrm{~m}^{2} / \mathrm{s}$ for the specimen with normal repair, $0.176 \times 10^{-12} \mathrm{~m}^{2} / \mathrm{s}$ for the NPM specimen, and $0.202 \times 10^{-12} \mathrm{~m}^{2} / \mathrm{s}$ for the SSM specimen - which is approximately $15 \%$ higher than that of NPM. This test result was also closely associated with the bacterial immobilization rate, and shows a consistent trend with the results in the reduction rate in compressive strength and mass.

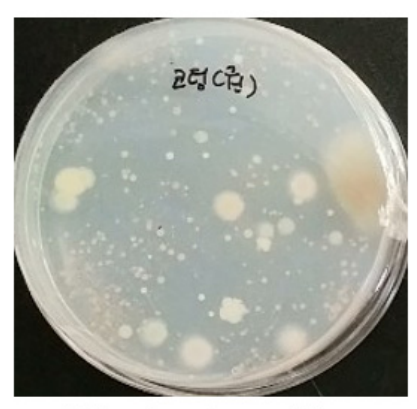

Bio-simply soaking

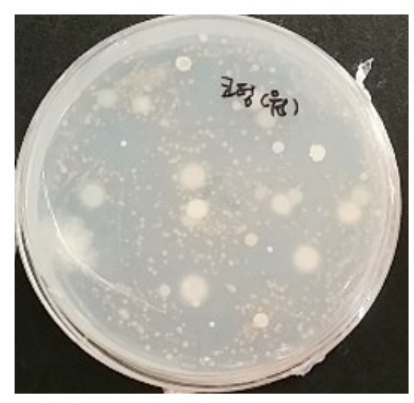

Bio-negative pressure

(a)

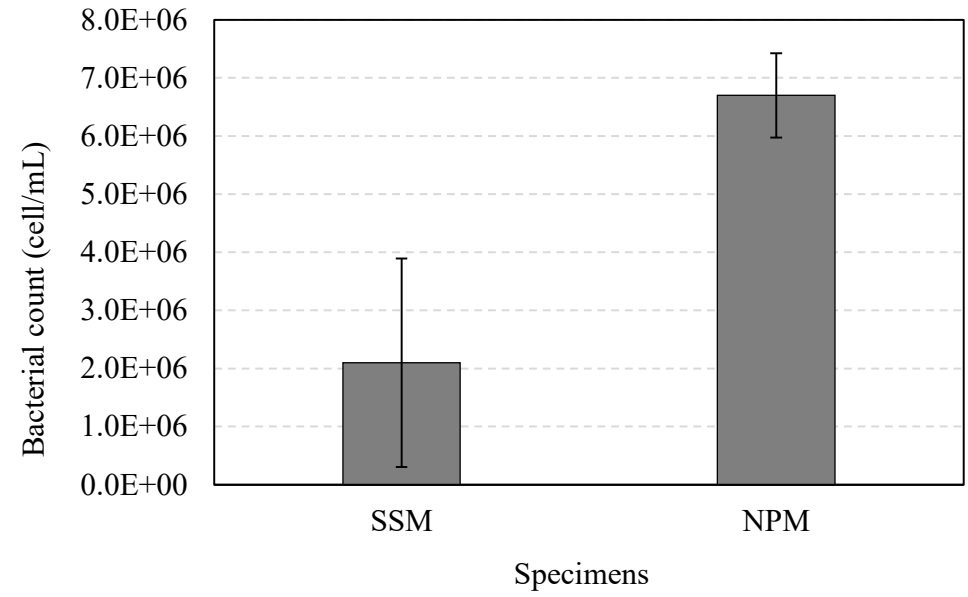

(b)

Figure 11. Results of the re-cultured bacteria from the coated concrete immersed in $5 \%$ sulfuric acid solution for 28 days: (a) re-cultured images; and (b) population of bacteria.

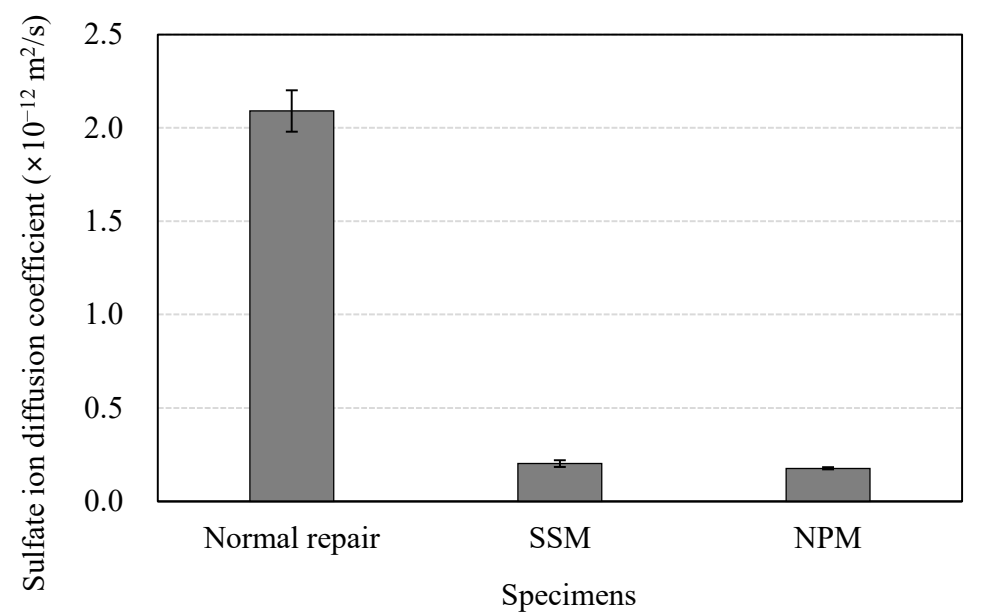

Figure 12. Results of the sulfate ion diffusion coefficient. 


\subsection{Chemical Property Evaluation through Surface Analyzing Techniques (XRD and TGA)}

Figure 13 shows the XRD analysis result of the sample collected from the inner concrete surface protected from the repair material after 28 days of immersion in $5 \%$ sulfuric acid solution. In the same figure, the XRD pattern of the sample taken from the concrete surface without exposure to sulfuric acid was also indicated as the comparative data (virgin concrete). In all samples, peaks such as gypsum and portlandite, which are cement hydrates, were formed, and the peak of ettringite, a reaction compound between gypsum and $\mathrm{C}_{3} \mathrm{~A}$, was also identified. However, the peak intensity of gypsum, a sulfuric aciddeteriorated hydrate that causes the expansion and cracking of the cement structure, was slightly different depending on the coating conditions. In the concrete surface coated with the normal repair without bacteria mixing, the peak intensity of gypsum was high at approximately $11-12^{\circ}, 31^{\circ}$ and $33^{\circ}$. On the other hand, the peaks of gypsum were not relatively high in the concrete surface coated with slime bacteria-mixed repair (SSM and NPM). In addition, the XRD patterns of these specimens were similar to those of virgin concrete, not deteriorated by sulfuric acid. These results indicate that when the repair mixed with slime-forming bacteria is applied, the base concrete can be reasonably protected from sulfate attack through the effect of inhibiting sulfate ingress by the slime, and deteriorated cement hydrates (gypsum) from sulfuric acid are not formed.

Furthermore, considering that the peak intensity of gypsum increases in the sample exposed to sulfuric acid deterioration, it can be expected that the peak intensity of ettringite is also increased. However, the XRD patterns for all samples showed a similar peak intensity of ettringite regardless of the application of bacteria. This is thought to be because ettringite loses stability in a low $\mathrm{pH}$ environment such as sulfuric acid solution and is easily converted to gypsum and aluminum sulfate [44].

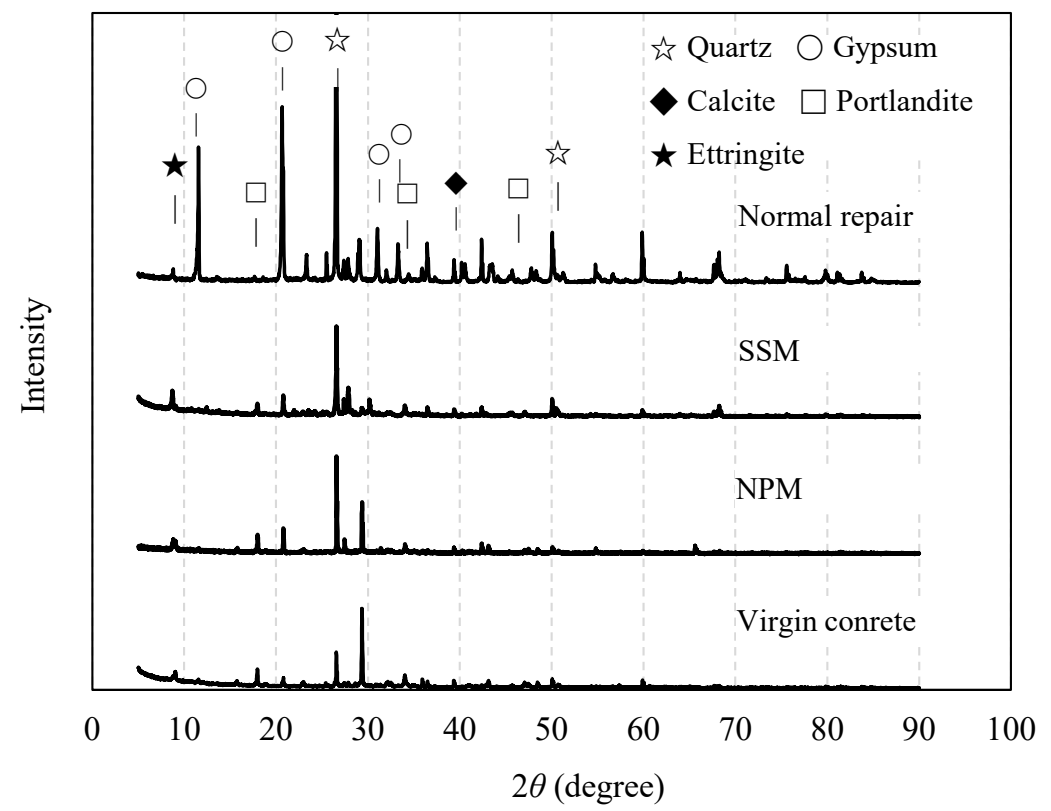

Figure 13. XRD patterns at the surface layer of coated concrete samples immersed in $5 \%$ sulfuric acid solution for 28 days.

Figure 14 shows the result of mass variation due to the thermal decomposition of hydrates in the samples taken from the concrete surface below the coating material. The specimens in the figure are of virgin concrete not affected by the sulfuric acid deterioration and the other specimens are those after 4 weeks of $5 \%$ sulfuric acid solution test (normal repair, SSM, and NPM). All specimens showed a decrease in mass due to thermal decomposition over various temperature ranges, including $60-250{ }^{\circ} \mathrm{C}$ and $450-500{ }^{\circ} \mathrm{C}$. Typical cement hydrates- $\mathrm{Ca}(\mathrm{OH})_{2}$ and calcite- show a mass reduction curve as they undergo thermal decomposition in the temperature ranges of $450-500{ }^{\circ} \mathrm{C}$ and $700-850{ }^{\circ} \mathrm{C}$, respec- 
tively. On the other hand, $\mathrm{C}-\mathrm{S}-\mathrm{H}$ does not show a clear reduction curve of mass variation at a specific temperature. The gypsum formed in the cement matrix was typically present in the form of dihydrate gypsum $\left(\mathrm{CaSO}_{4} \cdot 2 \mathrm{H}_{2} \mathrm{O}\right)$, and gradually starts to dehydrate at a temperature of $60-95{ }^{\circ} \mathrm{C}$. The gypsum changes to hemihydrate gypsum $\left(\mathrm{CaSO}_{4} \cdot 1 / 2 \mathrm{H}_{2} \mathrm{O}\right)$ through proper dehydration at a temperature of $95-175{ }^{\circ} \mathrm{C}$. Thereafter, it changes into anhydrous gypsum $\left(\mathrm{CaSO}_{4}\right)$ at approximately $250{ }^{\circ} \mathrm{C}$ due to continuous dehydration. The thermal decomposition of ettringite formed by the reaction of anhydrous gypsum with aluminate $\left(\mathrm{C}_{3} \mathrm{~A}, 3 \mathrm{CaO} \cdot \mathrm{Al}_{2} \mathrm{O}_{3}\right)$ occurs at approximately $88-105^{\circ} \mathrm{C}$, partially overlapping with the curve of the mass variation of gypsum $[43,45,46]$.

In the temperature range of $60-250{ }^{\circ} \mathrm{C}$, the mass reduction of the normal repair specimen without bacteria mixing was the largest at $11.4 \%$, which was approximately twice that of virgin concrete without sulfuric acid deterioration in this temperature range. On the other hand, in the case of bacteria-coated repair, the mass reduction due to the thermal decomposition of hydrates in the temperature range was $9.2 \%$ for the SSM specimen and only $7.7 \%$ for NPM specimen, indicating a reduction of $18 \%$ and $31 \%$ compared to the normal repair specimen, respectively. These results indicate that ettringite and gypsum, which are deteriorated hydrates formed by the reaction between the cement hydration products and sulfuric acid, are formed less in the case of applying repair mixed with bacteria, and even less in NPM. This also indicates that the larger bacterial count of the continuously growing bacteria is very effective to secure resistance to sulfuric deterioration.

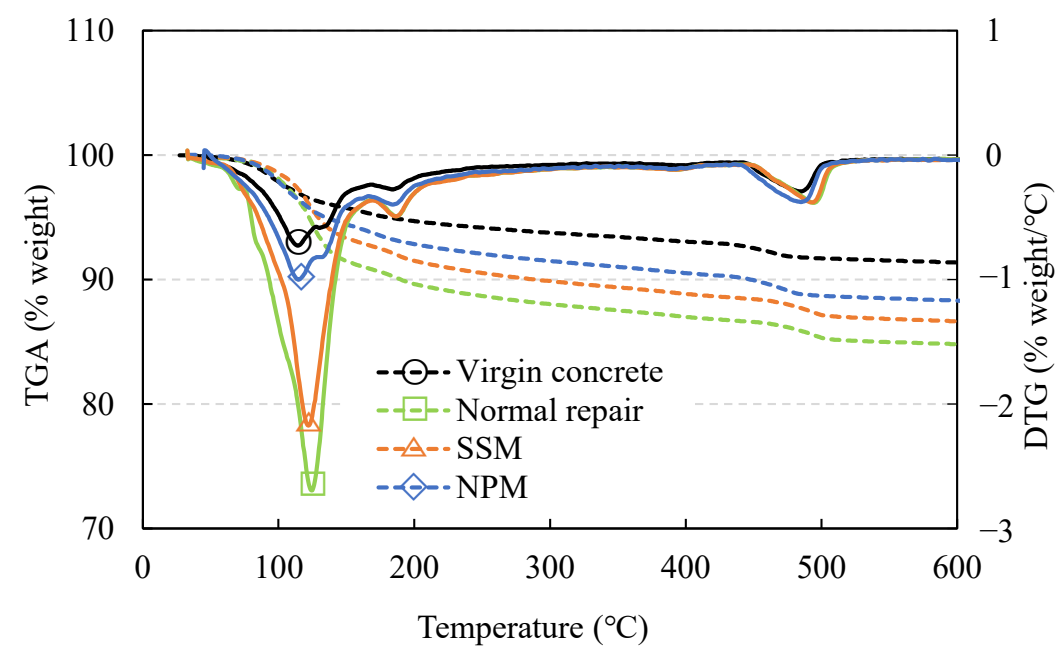

Figure 14. Thermal analysis of coated concrete samples immersed in 5\% sulfuric acid solution for 28 days.

\section{Conclusions}

In this study, a bio-coating material which is effective for enhancing resistance to sulfate ingress was developed using the NPM and an accelerated sulfate resistance test was performed to evaluate the applicability of the proposed technique. The repair material with bio-coating from NPM had excellent mechanical and durability characteristics. After the accelerated sulfate resistance test, the concrete surface under the coating material was analyzed by various methods and the derived results are outlined as follows:

- As a result of applying a negative pressure method (NPM) that forcibly removes the internal air through a pressure of 10-20 torr, it was possible to obtain the immobilization rate of Rhodobacter capsualtus 2.2 to 3.3 times that of the simple soaking method (SSM). The variation in strength was not significantly different between the two methods after 4 weeks of immersion in a $5 \%$ sulfuric acid solution.

- As a result of evaluating the decreasing rate in strength and mass after sulfuric acid immersion for the normal repair specimen, SSM specimen, and NPM specimen, resistance to sulfate was highest in the coating repair by NPM. In addition, the NPM 
specimen showed more than 3.0 times the bacterial count compared to the SSM specimen. The slime thickness of bio-coating was evaluated at $90 \mu \mathrm{m}$ from the SEM analysis and enhanced the resistance to sulfate ingress. The sulfate diffusion coefficient from NPM showed a lower result from SSM by $15 \%$, which was consistent with the test results of the strength and mass variation after sulfate acid immersion.

- The XRD analysis result confirmed that the effect of the sulfate ions which penetrated the bio-coating repair did not significantly affect the properties of the base concrete. In particular, the peak intensity of gypsum (acid-deteriorated hydrates) from XRD decreased in the bio-coating slime treated with NPM, which showed improved resistance to sulfate ingress. The TGA analysis in NPM also showed the mass reduction curve closest to that of the virgin concrete that is not affected by sulfate attack, which means that the repair material by the proposed NPM is highly effective to blocking the intrusion of sulfate ions and preventing the base concrete from sulfate ingress.

- The newly developed technique for NPM was effective to protect sulfate ion penetration; however, future research is still needed on quality control in the mass production of bio-coating material and the automated repairing method for coating thickness control.

Author Contributions: K.-H.Y.: conceptualization, formal analysis, writing-review and editing; S.-J.K.: formal analysis, methodology, supervision, writing—review and editing; H.-S.Y.: investigation, formal analysis, visualization, writing — original draft. All authors have read and agreed to the published version of the manuscript.

Funding: This research was supported by a grant (21SCIP-C158976-02) from the Construction Technology Research Program funded by the Ministry of Land, Infrastructure and Transport of the Korean government.

Institutional Review Board Statement: Not applicable.

Informed Consent Statement: Not applicable.

Data Availability Statement: The data presented in this study are available on request from the corresponding author.

Conflicts of Interest: The authors declare no conflict of interest.

\section{References}

1. Qin, S.; Zou, D.; Liu, T.; Jivkov, A. A chemo-transport-damage model for concrete under external sulfate attack. Cem. Concr. Res. 2020, 132, 106048. [CrossRef]

2. Sotiriadis, K.; Mácová, P.; Mazur, A.S.; Viani, A.; Tolstoy, P.M.; Tsivilis, S. Long-term thaumasite sulfate attack on Portlandlimestone cement concrete: A multi-technique analytical approach for assessing phase assemblage. Cem. Concr. Res. 2020, 130, 105995. [CrossRef]

3. European Committee for Standardization. Eurocode 1: Basis of Design and Actions on Structures; EN-1991; CEN (European Committee for Standardization): Brussels, Belgium, 2000.

4. Japan Society of Civil Engineering. Standard Specification for Concrete Structures-Design; JSCE Guidelines for Concrete; JSCE (Japan Society of Civil Engineering): Tokyo, Japan, 2007.

5. American Concrete Institute. Guide to Durable Concrete; ACI 201R-08; ACI (American Concrete Institute): Miami, FL, USA, 2008.

6. Ary, C.; Buenfeld, N.R.; Newmann, J. Factors influencing chloride binding in concrete. Cem. Concr. Res. 1990, 20, 291-300. [CrossRef]

7. Park, S.S.; Kwon, S.J.; Jung, S.H. Analysis technique for chloride penetration in cracked concrete using equivalent diffusion and permeation. Constr. Build. Mater. 2012, 29, 183-192. [CrossRef]

8. Maekawa, K.; Ishida, T.; Kishi, T. Multi-Scale Modeling of Structural Concrete; Taylor \& Francis: London, UK, 2009.

9. Wu, J.; Lepech, M.D. Incorporating multi-physics deterioration analysis in building information modeling for life-cycle management of durability performance. Autom. Constr. 2020, 110, 103004. [CrossRef]

10. Ishida, T.; Maekawa, K. Modeling of durability performance of cementitious materials and structures based on thermo-hygro physics. In Proceedings of the 2nd International RILEM Workshop on Life Prediction and Aging Management of Concrete Structures, Paris, France, 13-14 May 2003.

11. Song, H.W.; Kwon, S.J. Permeability characteristics of carbonated concrete considering capillary pore structure. Cem. Concr. Res. 2007, 37, 909-915. [CrossRef] 
12. Kwon, S.J.; Song, H.W. Analysis of carbonation behavior in concrete using neural network algorithm and carbonation modeling. Cem. Concr. Res. 2010, 40, 119-127. [CrossRef]

13. Zhang, M.; Yang, M.L.; Guo, J.J.; Liu, W.L.; Chen, H.L. Mechanical properties and service life prediction of modified concrete attacked by sulfate corrosion. Adv. Civ. Eng. 2018, 2018, 8907363. [CrossRef]

14. Atkinson, A.; Hearne, J.A. Mechanistic model for the durability of concrete barriers exposed to sulphate-bearing groundwaters. MRS Online Proc. Libr. Arch. 1989, 176, 149-156. [CrossRef]

15. Zhang, W.Q.; Liu, L.X.; Dai, D.H. Experimental study of concrete corroding in brine and fresh water under dry-wet circulation. J. Qinghai Univ. 2006, 4, 25-29.

16. Hadjmeliani, M. Degradation of sewage pipe caused Sinkhole: A real case study in a main road. In Proceedings of the AFM, Lyon, France, 24-28 August 2015.

17. Lee, H.J.; Cho, M.S.; Lee, J.S.; Kim, D.G. Prediction model of life span degradation under sulfate attack regarding diffusion rate by amount of sulfate ions in seawater. Int. J. Mater. Mech. Manuf. 2013, 1, 251-255. [CrossRef]

18. Jiang, C.; Jiang, L.; Li, S.; Tang, X.; Zhang, L. Impact of cation type and fly ash on deterioration process of high belite cement pastes exposed to sulfate attack. Const. Build. Mater. 2021, 286, 122961. [CrossRef]

19. Yang, K.H.; Lim, H.S.; Kwon, S.J. Effective bio-slime coating technique for concrete surfaces under sulfate attack. Materials 2020, 13, 1512. [CrossRef]

20. Yoon, H.S.; Yang, K.H.; Lee, K.M.; Kwon, S.J. Service life evaluation for RC sewer structure repaired with bacteria mixed coating: Through probabilistic and deterministic method. Materials 2021, 14, 5424. [CrossRef]

21. Vincke, E.; Van Wanseele, E.; Monteny, J.; Beeldens, A.; De Belie, N.; Taerwe, L.; Van Gemert, D.; Verstraete, W. Influence of polymer addition on biogenic sulfuric acid attack of concrete. Int. Biodeter. Biodegr. 2002, 49, 283-292. [CrossRef]

22. Vipulanandan, C.; Lui, J. Film model for coated cement concrete. Cem. Concr. Res. 2002, 32, 1931-1936. [CrossRef]

23. Yoon, H.S. Characteristics of Biomimetic Protective Coating Materials Using Bacteria Slime Immobilized by Negative Pressure for Concrete Exposed to Sulfate Attack. Ph.D. Thesis, Kyonggi University, Suwon, Korea, 2021.

24. Tziviloglou, E.; Wiktor, V.; Jonkers, H.M.; Schlangen, E. Bacteria-based self-healing concrete to increase liquid tightness of crack. Constr. Build. Mater. 2016, 122, 118-125. [CrossRef]

25. Chahal, N.; Siddique, R.; Rajor, A. Influence of bacteria on the compressive strength, water absorption and rapid chloride permeability of fly ash concrete. Constr. Build. Mater. 2012, 28, 351-356. [CrossRef]

26. Siddique, R.; Chahal, N.K. Effect of ureolytic bacteria on concrete properties. Constr. Build. Mater. 2011, 25, 3791-3801. [CrossRef]

27. Zhong, W.; Yao, W. Influence of damage degree on self-healing of concrete. Constr. Build. Mater. 2008, 22, 1137-1142. [CrossRef]

28. Wang, J.; Snoeck, D.; Van Vlierberghe, S.; Verstraete, W.; De Belie, N. Application of hydrogel encapsulated carbonate precipitating bacteria for approaching a realistic self-healing in concrete. Constr. Build. Mater. 2014, 68, 110-119. [CrossRef]

29. Jonkers, H.M.; Thijssen, A.; Muyzer, G.; Copuroglu, O.; Schlangen, E. Application of bacteria as self-healing agent for the development of sustainable concrete. Ecol. Eng. 2010, 36, 230-235. [CrossRef]

30. Ramachandran, S.K.; Ramakrishnan, V.; Bang, S.S. Remediation of concrete using micro-organisms. ACI Mater. J. $2001,98,3-9$.

31. Yang, K.H.; Yoon, H.S.; Lee, S.S. Feasibility tests toward the development of protective biological coating mortars. Constr. Build. Mater. 2018, 181, 1-11. [CrossRef]

32. Parker, C. The corrosion of the concrete, I. The isolation of a species of bacterium associated with the corrosion of concrete exposed to atmospheres containing hydrogen sulfide. Aust. J. Exp. Biol. Med. Sci. 1945, 23, 81-90. [CrossRef]

33. Khan, H.A.; Castel, A.; Khan, M.S.H. Corrosion investigation of fly ash based geopolymer mortar in natural sewer environment and sulphuric acid solution. Corros. Sci. 2020, 168, 108586. [CrossRef]

34. Monteny, J.; Vincke, E.; Beeldens, A.; De Belie, N.; Taerwe, L.; Van Gemert, D.; Verstraete, W. Chemical, microbiological, and in situ test methods for biogenic sulfuric acid corrosion of concrete. Cem. Concr. Res. 2000, 30, 623-634. [CrossRef]

35. De Belie, N.; Monteny, J.; Beeldens, A.; Vincke, E.; Van Gemert, D.; Verstraete, W. Experimental research and prediction of the effect of chemical and biogenic sulfuric acid on different types of commercially produced concrete sewer pipes. Cem. Concr. Res. 2004, 34, 2223-2236. [CrossRef]

36. Takahashi, H.; Kopriva, S.; Giordano, M.; Saito, K.; Hell, R. Sulfur assimilation in photosynthetic organisms: Molecular functions and regulations of transporters and assimilatory enzymes. Annu. Rev. Plant Biol. 2011, 62, 157-184. [CrossRef]

37. Barton, L.L. Sulfate-Reducing Bacteria; Springer: Boston, MA, USA, 1995.

38. Islander, R.L.; Devinny, J.S.; Mansfeld, F.; Postyn, A.; Shih, H. Microbial ecology of crown corrosion in sewers. J. Environ. Eng. 1991, 177, 751-770. [CrossRef]

39. Joseph, A.P.; Keller, J.; Bustamante, H.; Bond, P.L. Surface neutralization and H2S oxidation at early stages of sewer corrosion: Influence of temperature, relative humidity and H2S concentration. Water Res. 2012, 46, 4235-4245. [CrossRef]

40. Grengg, C.; Mittermayr, F.; Ukrainczyk, N.; Koraimann, G.; Kienesberger, S.; Dietzel, M. Advances in concrete materials for sewer systems affected by microbial induced concrete corrosion: A review. Water Res. 2018, 134, 341-352. [CrossRef] [PubMed]

41. Aviam, O.; Bar-Nes, G.; Zeiri, Y.; Sivan, A. Accelerated biodegradation of cement by sulfur-oxidizing bacteria as a bioassay for evaluating immobilization of low-level radioactive waste. Appl. Environ. Microbiol. 2004, 70, 6031-6036. [CrossRef] [PubMed]

42. Jung, S.H.; Ryu, H.S.; Kathick, S.; Kwon, S.J. Time and crack effect on chloride diffusion for concrete with fly ash. Int. J. Concr. Struct. Mater. 2018, 12, 227-236. [CrossRef] 
43. Yoon, H.S.; Yang, K.H.; Lee, S.S. Evaluation of sulfate resistance of protective biological coating mortars. Const. Build. Mater. 2021, 270, 121381. [CrossRef]

44. Bae, S.H.; Park, J.I.; Lee, K.M. Influence of mineral admixture on the resistance to sulfuric acid and sulfate attack in concrete. J. Korea Concr. Inst. 2010, 22, 219-228. [CrossRef]

45. Qoku, E.; Bier, T.A.; Westphal, T. Phase assemblage in ettringite-forming cement pastes: A X-ray diffraction and thermal analysis characterization. J. Build. Eng. 2017, 12,37-50. [CrossRef]

46. Elbeyli, I.Y.; Piskin, S. Thermal dehydration kinetics of gypsum and borogypsum under non-isothermal condition. Chin. J. Chem. Eng. 2004, 12, 302-305. 